\title{
Danuta Lech-Kirstein
}

Uniwersytet Opolski

\section{Nazwy roślin uprawnych w śląskiej toponimii}

\section{Wprowadzenie}

Dzieje rolnictwa w dawnej Rzeczpospolitej i na Śląsku nie były często opisywane zarówno przez rolników, jak i naukowców. Dopiero w ostatnich latach zaczęto interesować się tymi kwestiami, badając zagadnienia produkcji rolnej, uprawy roli i kultury ziemiopłodów, ogrodnictwa i sadownictwa, gospodarki łąkowej, pastwiskowej, leśnej, hodowli zwierząt, gospodarki stawowej, pszczelarstwa, browarnictwa, gorzelnictwa, młynarstwa i różnych dziedzin rzemiosła [Inglot 1954: V-VI].

Pierwsze książki rolnicze z XVI-XVIII w. były rezultatem rozległej, jednak naukowo niepogłębionej wiedzy ich autorów (np. książka Anzelma Gostomskiego z końca XVI w. czy Jakuba Kazimierza Haura z drugiej połowy XVII w.), dopiero Krzysztof Kluk wprowadził metodologię naukową do literatury rolniczej w drugiej połowie XVIII wieku [Inglot 1954: VII].

Przedmiotem mojego zainteresowania są nazwy miejscowe i terenowe Śląska notowane w Stowniku etymologicznym nazw geograficznych Ślaska [1970-2014]. Do analizy wybrałam bazy nazewnicze tworzące toponimy od nazw roślin uprawnych, na ich podstawie bowiem można zrekonstruować fragment językowego obrazu świata i wyciąnnąć wnioski na temat dawnej kultury ludowej, sposobów uprawy roli, ogrodnictwa i sadownictwa, medycyny naturalnej, obrzędów agrarnych, wierzeń, przesądów itp. ${ }^{1}$ Zapisy źródłowe ograniczyłam do pierwszej notacji, gdyż interesuje mnie motywacja nazwy w momencie jej nadania. $Z$ tego też powodu obok toponimów polskich pojawiają się nazwy niemieckie związane z kolonizacją średniowieczną (X-XII w.) oraz z wielką akcją osadniczą Fryde-

\footnotetext{
${ }^{1}$ Część analityczna ma charakter słownika gniazdowego. Po artykule hasłowym zawierającym poszczególne bazy toponimiczne podaję następujące informacje: pozycję w klasyfikacji naukowej, znaczenia słownikowe, pochodzenie leksemu, nazwy osobowe, derywaty apelatywne notowane w nazwach, przysłowia i frazeologizmy regionalne, wreszcie toponimy i mikrotoponimy Śląska pochodzące od danej bazy.
} 
ryka II w XVIII w. (tzw. kolonizacją fryderycjańską), w czasie których założono na Śląsku wiele nowych osad i wybudowano wiele gospodarstw we wsiach już istniejących. Data najstarszego poświadczenia nie zawsze jest równoznaczna $\mathrm{z}$ okresem powstania konkretnego toponimu, gdyż niektóre nazwy przetrwały przez wieki w postaci mikrotoponimów, a później określiły obiekty zamieszkałe, jak: części wsi, przysiółki, osady itp. [Borek 1998: 116].

\section{Rośliny zbożowe}

Najczęściej notowane w toponimii są nazwy zbóż. Grupa tych roślin wykorzystywana była od najdawniejszych czasów do celów konsumpcyjnych, pastewnych i przemysłowych. Zboża pełniły ważną funkcję w przemyśle spożywczym, a także w piwowarstwie, gorzelnictwie i farmaceutyce.

Proso // jagly // pszono // niem. Hirse - proso zwyczajne (Panicum miliaceum); jagty 'proso; ziarno prosa'< psł. *jagъly; pszono 'wymłócone proso' - jedna z najstarszych roślin zbożowych, uprawiana na kaszę jaglana, do karmienia kur i jako środek leczniczy przy gorączkach. Nie potrzebowała bardzo dobrej gleby [Kluk 2006: 138]. K. Moszyński podaje [1967: 224], że było to jedno z najważniejszych zbóż (jeśli nie najważniejsze) na znacznych obszarach Słowiańszczyzny i w całej Europie od neolitu.

Derywaty: jagielny 'przym. od jagły'; prośnisko 'miejsce, na którym rosło proso, ściernisko po prosie' [SD VII: 667]. Niektóre nazwy geograficzne moga pochodzić od nazwisk Jagło, Jagła (1387). Ogólnie znane przysłowie: Kto sieje proso, ten chodzi boso [Kop 489] wskazuje na to, że proso było zbożem uprawianym przez biedotę.

Hirseberg, pol. Jaglarz; góra; Pog. Kaczawskie, Sudety Zach.; Jagielnia (Jagielna Mühle); cz. mta; Knurów, p. gliwicki, śl.; Jagielnia; daw. kol.; wś Brzezie, obecnie mto Racibórz, p. raciborski, śl.; Jagielniak; staw; wś Laskowice, g. Lasowice Wielkie, p. kluczborski, opol.; Jagielno (Deutsch Jägel); wś; g. Przeworno, p. strzeliński, dlś.; Jagielno; n. ter.; przys. Brzeziak, g. Krzyżanowice, p. raciborski, śl.; Jaglauermühle; młyn; Stare Więckowice, dziś cz. mta Gorzów Śląski, p. oleski, opol.; Jegielnica; wś; gm. Korfantów, p. nyski, opol.; Jeglowa; wś; g. Przeworno, p. strzeliński, dlś; Prosna; n. ter.; okolica Przylepu, g. Zielona Góra, p. zielonogórski, lubus.; Prośniska; n. leśna; leśniczówka Tychy, śl.; Prośniska; cz. lasu; g. Kędzierzyn-Koźle, p. kędzierzyńsko-kozielski, opol.; Pszonek; staw; daw. p. jeleniogórski, dśl.

$\dot{Z} \boldsymbol{y}$ to // $\boldsymbol{r e} \dot{\boldsymbol{z}}$ - (Secale cereale L.) znane było wszystkim Słowianom, ale uprawiane było najczęściej w krajach północnych (także w Polsce), a także górzystych lub piaszczystych [Moszyński, 1967: 234]. Prasłowiańskie *žito oznaczało wszelkie rośliny zbożowe jako dające życie, służące do utrzymania życia, natomiast dla określenia opisywanej rośliny zbożowej używano w prasłowiańszczyźnie leksemu *rzžb, stąd w polszczyźnie rżysko [Sędz 10]. 
Derywaty: żytny 'przym. od żyta', daw. 'zbożowy', też ‘żyzny', por. też żytnik 'motylek nocny składający jaja w zbożach' [SL VI: 1209]. W przysłowiach śląskich żyto jest symbolem bogactwa i dobrobytu: Gdo mo żytko, mo wszystko [Ond 65]; Mojiściewy! - Reż, ni plewy! [Ond 126]; Nie bydzie z tej rży placek // maka [Ond 140-141]; Ni ma dla siedloka, jak reżny chlyb a bukowe drzewo [Ond 150].

Żytarka; n. leśna, leśn. Waszczyce, g. Orzesze, p. mikołowski, śl.; Żytarki; n. leśna, leśn. Waszczyce, g. Orzesze, p. mikołowski, śl.; Żytna; wś; g. Lyski, p. rybnicki, śl.; Żytna-Obchód; przys. g. Lyski, p. rybnicki, śl.; Żytnik; wzgórze 157 m; p. lubiński, dśl.; Żytni Młyn; gajówka; Nabłoto, g. Brody, p. żarski, lubus.; Żytniów; wś; g. Rudniki, p. opolski, dśl.; $\dot{Z} \boldsymbol{y} t \boldsymbol{t n o}$; cz. mta; Oborniki Śl., p. trzebnicki, dśl.; Żytowań; wś; g. Gubin, p. krośnieński, lubus.

Owies // niem. Hafer - 'Avena, roślina z rodziny traw o kłoskach dwukwiatowych lub wielokwiatowych zebranych w wiechę; obejmuje gatunki dzikie i uprawne; z uprawnych najbardziej znany jest owies zwyczajny (Avena sativa) stanowiący paszę koni i bydła' [SD V: 1239]. Zboże to było także stosowane jako roślina lecznicza. Na Opolszczyźnie podawano wywar z ziaren owsa przy leczeniu robaczyc, a w celu obniżenia nadciśnienia pito wywar z plew owsianych. Wywaru ze słomy owsianej używano przy uporczywym kaszlu i kąpano się w nim przy padaczce i świerzbie, wykorzystywano go również do okładów w leczeniu ropnych chorób skóry. W czasie kolki nacierano też brzuch rozgrzanym owsem [Pół 68-90].

Psł. *ovbsb. Derywaty potwierdzają produktywność bazy owies $w$ apelatywach: owiesny, owsiany, owsianka, owieśny 'przełożony nad owsami, piwniczny' [SL III: 632]; owsiszcze, owsisko < psł. *ovbsišče, *ovbsisko 'pole zasiane owsem' [Sędz 94].

Przysłowia świadczą o tym, że owies był spożywany przez biedotę wiejską i uważany za przysmak dla zwierząt: Biyda od gynsi dostać owsa [Ond 24]; Fajnidełko z miasta nie zjy z owsa ciasta [Ond 61]; Gazdoszku, latoś wóm urós owies żabie po uszy [Ond 62]; I w Paryżu nie zrobióm z owsa ryżu [Ond 81]; Jak sie chce jeść, to i placek z owsa dobry [Ond 89]; Kónia poganiajóm owsym, a nie biczym [Ond 109]. Podkreślają też, że praca przy jego uprawie była ciężka, porównywalna z mękami piekielnymi: Pujdziesz (!) do piekła owies przewracać [Ond 178]; Jak sie mosz? - Lepszy by już było na owsisku [Ond 90].

Haferberg, dziś Owiesno; wzgórze; daw. p. oławski, dśl.; Haferberg, dziś Owsianka; wzgórze; daw. p. wrocławski, dśl.; Haferberg, dziś Owsisko; wzgórze; daw. p. brzeski, opol.; Owiesno (Habendorf, Habirsdorf); wś; g. Dzierżoniów, p. dzierżoniowski, dśl.; Owsiszcze (Owschütz, Habergrund); wś; g. Krzyżanowice, p. raciborski, śl.

Pszenica // *psza // golka // niem. Weizen - jest to najszlachetniejsze ze zbóż, potrzebujące najlepszej ziemi, uprawiane dla pożywienia (chleba, mąki, kaszy, piwa, wódki). Wśród gatunków pszenicy Kluk wymienia kosmatkę, której kłosy są ościste $i$ gołkę o kłosach pozbawionych ości [2006: 126], por. też goła, gołka 
'teren goły'. Der Weizen 'pszenica'; psł. *pbšenica; niezachowany w języku pol. wyraz *psza 'pszenica', por. psz-ono, psz-en-ica, stp. samopsza.

W przysłowiach pszenica jest metaforą dobrobytu, życia dostatniego, pozbawionego trosk: Cudzóm pszynice oganio, a jego wróble dziubióm. [Ond 42]; Lepszy młócić cudzóm pszenice, niż swoji plewy. [Ond 115]; Na jednej ziemi kónkol i pszenica rośnie. [Ond 136].

Gotka; n. ter.; Gatka, g. Żmigród, p. trzebnicki, dśl.; Golka; n. ter.; g. Bierawa, p. kędzierzyńsko-kozielski, opol.; Pszów (Pschow); mto; p. wodzisławski, śl.; Weizen Berg, dziś Pszeniczna Góra; wzniesienie; daw. p. sycowski, dśl.

Pozostałe rośliny zbożowe nie były wykorzystywane w nazewnictwie Śląska. $\mathrm{W}$ jednym tylko przypadku zanotowano podstawę jęczmień, ale nie ma pewności, czy nazwę właściwie odczytano (por. Jęczmień (?); n. ter.; ok. wsi Klenica, g. Bojadła, p. zielonogórski, lubus.).

\section{Rośliny przemysłowe}

Rośliny przemysłowe specjalne i włókniste wykorzystywane były jako surowiec w przemyśle piwowarskim, włókienniczym i tytoniowym.

Chmiel // niem. Hopfen - 'chmiel, Humulus, roślina z rodziny konopiowatych' [SD I: 878], rosła dziko, ale niektóre jej gatunki, jak chmiel pospolity, $\mathrm{Hu}$ mulus lupulus uprawiano i wykorzystywano do produkcji piwa [Kluk 2006: 292].

Trzeba zaznaczyć, że na Śląsku używano także chmielu w celach leczniczych: w powiecie katowickim pito wywar z liści chmielu przy reumatyzmie i nerwicy, a także myto nim głowę przy silnych bólach [Wall 22]. W zielnikach pisano, że chmiel od wieków uważany był za środek uspokajający i nasenny. Odgrywał też dużą rolę w obrzędach weselnych: znana jest na przykład, pochodząca jeszcze z pogańskich czasów, pieśń o chmielu, śpiewana przez zamężne kobiety przy oczepinach [Byst 50].

Psł. *chъmeljb. O produktywności bazy chmiel świadczą liczne derywaty: chmielina 'gałązka, pęd chmielny' [SD I: 879], chmielinowy 'mający chmieliny' [SW I: 286], chmielnik 'plantacja chmielu' [SD I: 879], chmielarz 'uprawiający chmiel, handlujący chmielem' [SD I: 879], też 'pijak, włóczęga' [SW I: 286], przym. chmielowy, chmielny, przen. chmielny, podchmielony 'pijany' [SD I: 879], chmielić 'zaprawiać chmielem' [SL I: 250], chmielisko 'ogród chmielowy' [SL I: 251].

W przysłowiach chmiel pojawia się sporadycznie i podkreśla odurzające właściwości rośliny: Sztyrze Niymcy, wiertel chmiela, jeszcze im pómocy trzeba [Ond 193].

Chmiele; n. ter.; dziś mto Mikołów, p. mikołowski, śl.; Chmieliska, Chmielisk; n. ter.; daw. nadleśnictwo Ściernie, g. Bieruń, p. bieruńsko-lędziński, śl.; Chmieliskie; n. ter.; g. Reńska Wieś, p. kędzierzyńsko-kozielski, opol.; Chmielistwo; n. ter.; g. Prószków, p. opolski, opol.; Chmielni- 
$\boldsymbol{c e}$; n. ter.; g. Głogówek, p. prudnicki, opol.; Chmielniczyska, Chmielniczysk; n. ter.; dziś cz. mta Orzesze, p. mikołowski, śl.; Chmielnik; n. ter.; Bojszowy, g. Bojszowy, p. bieruńsko-lędziński, śl.; Chmielnik (Hopfengarten); cz. wsi; Kornice, g. Pietrowice Wielkie, p. raciborski, śl.; Chmielnik (Hopfenberg); góra; Kotlina Jeleniogórska i Wzgórza Łomnickie, Sudety Zach.; Chmielnik (Hopfenberg); góra; Kotlina Kłodzka, Sudety Środ.; Chmielnik; n. ter.; g. Kędzierzyn-Koźle, p. kędzierzyńsko-kozielski, opol.; Chmielnik, też Kruczy; n. ter.; g. Pietrowice Wielkie, p. raciborski, śl.; Chmielnik; n. ter.; g. Rudziniec, p. gliwicki, śl.; Chmielnik; n. ter.; daw. p. gliwicki, śl.; Chmielnik; n. ter.; g. Gorzów Śląski, p. oleski, opol.; Chmielnik; n. ter.; g. Pietrowice Wielkie, p. raciborski, śl.; Chmielnik; n. ter.; g. Cisek, p. kędzierzyńsko-kozielski, opol.; Chmielnik; n. ter.; g. Polska Cerekiew, p. kędzierzyńsko-kozielski, opol.; Chmielnik; n. ter.; daw. p. gliwicki, śl.; Chmielnik; n. ter.; g. Biała, p. prudnicki, opol.; Chmielnik; n. ter.; g. Głogówek, p. prudnicki, opol.; Chmielnik; n. ter.; g. Głogówek, p. prudnicki, opol.; Chmielnik; n. ter.; g. Cisek, p. kędzierzyńsko-kozielski, opol.; Chmielniki; n. ter.; g. Rudziniec, p. gliwicki, śl.; Chmielniki; n. ter.; daw. p. strzelecki, opol.; Chmielniki; n. ter.; g. Strzelce Opolskie, p. strzelecki, opol.; Chmielniki; łąki; daw. p. gliwicki, śl.; Chmielniska; n. ter.; g. Cisek, p. kędzierzyńsko-kozielski, opol.; Chmielniska; pole; daw. p. oleski, opol.; Chmielowice (Hopfental, Chmielowitz); wś; g. Komprachcice, p. opolski, opol.; Chmielów (Schmellwitz), też Śmiłowice; wś; g. Kostomłoty, p. średzki, dlś; Chmieluk (?); n. ter.; g. Głogówek, p. prudnicki, opol.; Hopfenberg, dziś Chmiel; góra; Pog. Izerskie, Sudety Zach.; Hopfenberg, dziś Chmielina; góra; G. Sowie, Sudety Środ.; Hopfenberg, dziś Chmielarz; góra; G. Kaczawskie, Sudety Zach.; Hopfenberg, dziś Chmielec; góra; Pog. Kaczawskie, Sudety Zach.; Hopfenberg, dziś Chmieliniec; góra; Pog. Bolkowskie, Sudety Środ.; Hopfenberg, dziś Chmielnik; kol.; Pawłów, g. Pietrowice Wielkie, p. raciborski, śl.; Hopfenberge, dziś Chmieliny, Chmielin, pot. Chmielowa Góra, Kopalnia; wzgórza; daw. p. zgorzelecki, dśl.

Winorośl // wino // niem. Weine - 'Vitis vinifera, roślina pnąca z rodziny winoroślowatych, uprawiana w klimacie ciepłym w licznych odmianach ze względu na jadalne owoce, używane także do wyrobu win' [SD IX: 1113]. Do Polski uprawa winorośli dotarła wraz z chrześcijaństwem, a za prekursorów winiarstwa uważa się powszechnie zakonników, którzy zakładali winnice i produkowali wino na potrzeby liturgiczne. W XV i XVI w. zaczęto uprawiać wina w celach handlowych, przy czym jednym z ważniejszych ośrodków winiarstwa jest Śląsk (od Raciborza przez Lubiąż i Trzebnicę po Głogów). W w. XVII uprawy zaczęły maleć z powodu ochłodzenia klimatu i rozpowszechnienia się eksportu z zagranicy [WE XXIX: 350].

Psł. *vino. Derywaty: wino 'sok tłoczony z winogron i poddany fermentacji; też winorośl' [SL VI: 332], winograd 'ogród winny, sad winny, winnica' [SL VI: 619], winnica, winnik 'ogród winny', winiarz 'właściciel winnicy, sprzedawca win, pracujący w winnicy' [SWil II: 1862], gw. winiar 'produkujący wino' [SGP VI: 127], przym. winny.

Przysłowia ludowe podkreślają przede wszystkim odurzające i rozgrzewające właściwości wina: Jak ci zima - kup se wina, jak ci ciepło - kup se piekło. [Ond 83]; Nie pij wina, kiejś chudzina. [Ond 145]; Pańsko taska i wino przez noc wywietrzóm. [Ond 162]; Z wina dobro nowina. [Ond 239].

Am Weinberge, pol. Winnogóra; wzgórze; Gierałcice, g. Wołczyn, p. kluczborski, opol.; Aufm Weinberg, pol. Na Góry; n. ter.; Markotów, g. Wołczyn, p. kluczborski, opol.; Die Wenske Wiesen, pol. Wińskie Łąki łąki; Stobrawa, g. Popielów, p. opolski, opol.; in Winar; pol. Winnica; wś; g. Krotoszyce, 
p. legnicki, dśl.; Uino, później †Wino; osada; okolice Sobótki, p. wrocławski, dśl.; Vin, dziś Wińsko; mto; p. wołowski, dśl.; von Wyna, dziś Winów; wś; g. Prószków, p. opolski, opol.; Vorwerk Weingarthen, później †Winograd; folwark; Cieszyn, p. cieszyński, śl.; Wein Berg, pol. Winna Góra; wzgórze; Pog. Izerskie, Sudety Zach.; Wein Berg, pol. Dębicz; wzgórze; leśn. Potoczek, g. Jerzmanowa, p. głogowski, dśl.; Wein Berg, pol. Kłodna; wzgórze; daw. p. średzki, dśl.; Wein Berg, pol. Kobielanka; wzgórze; daw. p. grodkowski, opol.; Wein Berg, Krzydłowickie Wzgórze; wzgórze koło wsi Krzydłowice, g. Grębocice, p. polkowicki, dśl.; Wein Berg, pol. Lipnicka Górka; wzgórze koło wsi Lipnica, g. Wołów, p. wołowski, dśl.; Wein Berg, pol. Męciniecka Góra; wzgórze; wś-g. Męcinka, p. jaworski, dśl.; Wein Berg, pol. Polna; wzgórze; daw. p. zgorzelecki, dśl.; Wein Berg, pol. Polna; wzniesienie; daw. p. zgorzelecki, dśl.; Weinackerei, później †Winnica; zabudowania do wsi-g. Stoszowice, p. ząbkowicki, dśl.; Weinbach, pol. Koźlanka; potok; lewy dopływ Śląskiej Ochli, dorz. Odry; Weinberg, pol. Winna Góra; wś; g. Jordanów Śląski, p. wrocławski, dśl.; Weinberg, pol. Winna Góra; cz. wsi; wś-g. Pokój, p. opolski, opol.; Weinberg, pol. Winniki; osada; Mikowice, g. Namysłów, p. namysłowski, opol.; Weinberg, pol. Winnogóra; wzgórze koło Sycowa, p. oleśnicki, dśl.; Weinberg, pol. Winnogóra; wzniesienie koło Lubiąża, g. Wołów, p. wołowski, dśl.; Weinberg, pol. Winna Góra; wzgórze; Tylice, g. Zgorzelec, p. zgorzelecki., dśl.; Weinberg, pol. Winne Wzgórze; wzgórze koło Lipnicy, g. Wołów, p. wołowski, dśl.; Weinberg, pol. Winnica; wzgórze; Cieplice Śląskie-Zdrój, dziś Jelenia Góra, p. jeleniogórski, dśl.; Wein-Berg, pol. Winna; góra; Pog. Kaczawskie, Sudety Zach.; Weinberg oder das kleine Schlossvorwerk, później †Winnica; osada; Syców, p. oleśnicki, dśl.; Wein-Berg, pol. Czubatka; wzgórze; daw. p. wołowski, dśl.; Wein-Berg, pol. Dębrznica, pot. Winnica; wzgórze; daw. p. strzelecki, opol.; Wein-Berg, pol. Dlużec; wzgórze; okolice Grodziszcza, g. Grębocice, p. polkowicki, dśl.; Wein-Berg, pol. Drzewica, też Za Wsia; wzgórze; daw. p. średzki, dśl.; Wein-Berg, pol. Glinki; wzgórze; daw. p. legnicki, dśl.; Wein-Berg, pol. Golina; wzgórze; daw. p. strzeliński, dśl.; Wein-Berg, pol. Gozdnik, też Winna Góra; wzgórze; daw. p. dzierżoniowski, dśl.; Wein-Berg, pol. Grabnik; wzgórze; daw. p. średzki, dśl.; Weinberg, pol. Kierzna; wzgórze; daw. p. jaworski, dśl.; Weinberg, pol. Kopiec; wzgórze; daw. p. milicki, dśl.; Weinberg, pol. Leśna; wzgórze; daw. p. żagański, lubus.; Weinberg, pol. Powinnik; góra; daw. p. głubczycki, opol.; Weinberg, pol. Winnik; wzgórze; daw. p. lubiński, dśl.; Weinberg, pol. Winnogóra; wzgórze; daw. p. milicki, dśl.; Weinberg, Winna Góra, pol. †Winna Góra; zabudowania; Siedlce, g. Oława, p. oławski, dśl.; Weinberg, Winna Góra, Kierzna Góra, dziś Winna Góra; wzniesienie; wś-g. Mściwojów, p. jaworski, dśl.; Weinberg, Winnogóra, pol. Winnik; wzgórze; Uciechów, g. Dzierżoniów, p. dzierżoniowski, dśl.; Wein-Berge, pol. Winna Góra; wzgórze koło Pasiecznej, g. Jaworzyna Śląska, p. świdnicki, dśl.; Weinberge, pol. Winniki; wzgórze; daw. p. świdnicki, dśl.; Weinberghof, później †Winniki; osada; Wojbórz, g. Kłodzko, p. kłodzki, dśl.; Weinbergvorwerk, pol. Winowno; osada; Bogomice, g. Kotla, p. głogowski, dśl.; Weingardten, pol. Winna Struga; n. ter.; Stary Popielów, dziś wś-g,. Popielów, p. opolski, opol.; Weingarten, pol. Sadowskie; łąki; Sady, g. Niemodlin, p. opolski, opol.; Weingassen, pol. Winiary; cz. mta Głogówek, p. prudnicki, opol.; Weingrund, pol. Pod Lasem; pole; daw. p. lubiński, dśl.; Winbergk, później †Winna Góra; osada do Brunowa, g. Lwówek Śląski, p. lwówecki, dśl.; Winica, dziś Winnica; n. ter.; Grzędzin, g. Polska Cerekiew, p. kędzierzyńsko-kozielski., opol.; Winice, dziś Winnice; n. ter.; Krapkowice, p. krapkowicki, opol.; Winicen, dziś Winnice; n. ter. między Wydrowicami i Sadami, g. Niemodlin, p. opolski, opol.; Winna Góra, Weinberg; góra; Kotlina Kłodzka, Sudety Środ.; Winna Góra, Wein-Berg; wzgórze; Mościsko, g. Dzierżoniów, p. dzierżoniowski, dśl.; Wein Berg, pol. Sosnówka; wzgórze; daw. p. grodkowski, opol.; Wein Berg, pol. Trzęsowskie Wzgórze; wzgórze koło Trzęsowa, g. Grębocice, p. polkowicki, dśl.; Wein Berg, pol. Zielnik; wzgórze; daw. p. jaworski, dśl.; Wein Berg, pol. Zielona Góra; wzgórze; daw. p. milicki, dśl.; Wein Berg, pol. Zabucze; wzgórze; daw. p. wołowski, dlś.; Wein-Berg, pol. Chmielnik, pot. Koło Dudy; wzgórze; daw. p. legnicki, dlśl.

Niektóre toponimy zawierające nazwy roślin uprawnych są znakiem konkretnych czasów i wydarzeń. Tak na przykład nazwy geograficzne z bazami tytoń lub tabaka wiążą się z masowym w XVIII-XIX w. przemytem na pograniczu 
prusko-austriackim. Wiele dróg i ścieżek w górach nosi nazwy oparte na tych podstawach, np. Tabaksteig, dziś Tabaczana Ścieżka; droga leśna, Kowarski Grzbiet, wschodnie Karkonosze; Tabaksweg, dziś Tytoniowa Ścieżka; ścieżka, Grzbiet Kamieniecki, G. Izerskie, Sudety Zach.; Tabaksborn, dziś Tytoniowe Źródlo; źródełko; Grzbiet Kamieniecki, G. Izerskie, Sudety Zach.

Rośliny włókniste, takie jak len czy konopie, służyły do wyrobu sznurów, lin, płótna, a także do produkcji oleju. Uprawiane też były w celach leczniczych. Nieczęsto w toponimii śląskiej utrwalone są nazwy gatunków tych roślin, por. Konopowiec Przedni i Zadni; n. leśne; leśn. Czarków, g. i p. Pszczyna, śl. (od konopie 'roślina przemysłowa włóknista, Cannabis', może od n. os. Konopa) i *Lniszcze, dziś Ilnica; przys. do wsi Ramułtowice, g. Kostomłoty, p. średzki, dśl.; według zapisów pierwotna nazwa to *Lniszcze < psł. *lbnišče 'pole, gdzie uprawiano len' [Sędz 97] (od len zwyczajny 'roślina jednoroczna z rodziny lnowatych, Linum usitatissimum').

\section{Rośliny okopowe i warzywne}

Określenia gatunkowe roślin okopowych bardzo rzadko były na Śląsku podstawami nazw geograficznych. Brak wyrazu toponimicznego kartofle spowodowany mógł być tym, że przez długi czas roślina ta nie była uprawiana w naszym kraju. Początkowo była uważana za szkodliwą, później sadzona w ogrodach królewskich, a dopiero rozporządzenia władz pruskich upowszechniły jej uprawę na Śląsku [Inglot 1954: CIV-CVI] ${ }^{2}$. W nazewnictwie śląskim zachowały się jedynie nazwy z podstawą ziemniak (por. Ziemniak; folw.; wś Dębina; gm. Jelcz-Laskowice, p. oławski, dśl) i nazwa gwarowa knule 'ziemniaki' od niem. die Knolle 'bulwy' (por. Na Knule; pole; wś Siołkowice Stare, g. Popielów, p. opolski, opol.).

Groch // niem. Erse - 'Pisum sativum, roślina pnąca uprawiana dla jadalnych strąków i nasion' [SD II: 1301]. Służyła też do nawożenia gleby. Oprócz znaczenia konsumpcyjnego miała znaczenie w obrzędach ludowych [Sędz 17].

Psł. *gorchъ. Derywaty z bazą groch są bardzo liczne: grochowina 'pole grochowe' lub 'słoma z wymłóconego grochu, uprawianego na suche ziarno', grochowisko, grochowiszcze 'pole zasiane grochem' [SW I: 908], grochowy 'przym. od groch', por. też grochowiec 'akacja' [SW I: 908]. Niektóre nazwy mogą pochodzić od n. os. Groch (1440).

Bardzo liczne są też przysłowia zawierające leksem groch, podkreślające kształt, właściwości rośliny i jego powszechność w wiejskich chatach: Lepszy groch doma, niźli w gościnie zwierzyna [SL II: 123]; Gdo idzie do grochu, to mu koszule sewlekóm [Ond 63]; godej, co chcesz, jagby groch na ściane ciepot [Ond

${ }^{2}$ Wydaje się to dziwne, gdy weźmiemy pod uwagę etymologię leksemu kartofel $<$ niem. Kartoffel 'ziemniak'. 
74]; groch wre pod pokrywkóm [Ond 76]; Kluski z mydlym, groch z powidlym, kapusta ze zielym - to czuć troche wiesielym [Ond 106]; Mo sie jak groch przi ceście, gdo idzie, każdy rwie [Ond 129].

Erbsen-Berg, też Polna Góra; góra; wś Borówno, gm. Czarny Bór, p. wałbrzyski, dśl; Grochowiec; pole; wś Kobyla Głowa, g. Ciepłowody, p. ząbkowicki, dśl.; Grochowina; n. ter.; daw. p. lubliniecki, śl.; Grochowiszcza, dziś Grochowiska; wś; g. Ząbkowice Śl., p. ząbkowicki, dśl.; Grochowiska; łąka; Łęg, g. Nędza, p. raciborski, śl.; Grochowiska; n. ter.; Borucice, g. Lubsza, p. brzeski, opol.; Grochowiska; n. leśna; mto i p. Mysłowice, śl.; Grochowisko; n. ter.; Dziergowice, g. Bierawa, p. kędzierzyńsko-kozielski, opol.; Grochów; wś; g. Gubin, p. krośnieński, lubus.

\section{Rośliny sadownicze}

Rośliny sadownicze uprawiane były dla jadalnych owoców w sadach, ogrodach i na plantacjach. Owoce te miały dla tutejszej ludności znaczenie użytkowe, lecznicze i magiczne.

Malina - 'malina właściwa (Rubus idaeus L.), półkrzew o smacznych, czerwonych owocach, rosnący dziko lub uprawiany w ogrodach' [SD V: 403]. Powszechnie używano soku z malin i wywaru z suszonych owoców przeciw gorączce. Uznawano też, że napar z liści ma zdolności wzmacniające. Liście z malin, tzw. maliniok, podawane były jako składnik codziennej herbatki ziołowej [Tylk 121].

Derywaty: zdr. malinka; malinie 'miejsce porośnięte malinami', maliniec, maliniak 'zarośla malin', też maliniak, malinik, malinnik 'napój alkoholowy z malin' [SL III: 30].

Przysłowia podkreślają słodycz i piękno owoców maliny: Dziołcha jak malina [Ond 58]; Moja bździnka jak malinka, twoja bździna jak zdechlina [Ond 126]; Nie każdo jagoda malina, bywo czasym i smrodynia [Ond 144].

Malin (Mahlen); wś; g. Wisznia Mała, p. trzebnicki, dśl.; Malina (Malino, Malsdorf); cz. mta; Opole, opol.; Malina (Maline); cz. wsi; Brenna, p. cieszyński, śl.; Maliniak; n. leśna; leśniczówka Suszec, g. i p. Żory, śl.; Maliniak; n. leśna; Rachowice, g. Sośnicowice, p. gliwicki, śl.; Maliniec; n. ter.; Tuły, g. Lasowice Wielkie, p. kluczborski, opol.; Malinik; n. leśna; leśniczówka Cielmice, dziś mto Tychy, śl.; Malinka; cz. mta; Wisła, p. cieszyński, śl.; Malinka; cz. wsi; Brenna, p. cieszyński, śl.; Malinka; góra; Brenna, p. cieszyński, śl.; Malinie (Gwosdzianer Mühle, Brechenmühle), dziś Maliny; cz. wsi; Gwoździany, g. Pawonków, p. lubliniecki, śl.; Malińce; las; Ryczeń, g. Góra, p. górowski, dśl.; Malnie (Mallnie, Odergrund); wś; g. Gogolin, p. krapkowicki, opol.; Malinie, dziś Malenie; cz. wsi; Leszczyny, g. i p. Bielsko-Biała, śl.; Maliny; n. leśna; leśniczówka Śmiłowice, dziś mto Mikołów, śl.

Jabłoń // jabłonka // łuż. gablenz - 'Pirus malus, drzewo owocowe uprawiane w sadach, najbardziej rozpowszechnione w klimacie umiarkowanym' [SD III: 293]. Niektóre nazwy pochodzą od jabło < psł. *ablo (jak w czes.), inne od jabłonka 'mała jabłon'. 
W przysłowiach jabłko jest zwykle metaforą człowieka i ludzkiego życia: Jabko od jabłónie daleko sie nie odkulo [Ond 81]; Ni ma stodszego jabka, jak wtośno matka [Ond 150]; Po tela wisi jabko na jabtóni, aż spadnie [Ond 169]; Ugryzionego jabka już żodyn nie podniesie [Ond 214].

Jabłacz; n. ter.; Stare Budkowice, g. Murów, p. opolski, opol.; Jablacz; pole; Budkowice, g Łubniany, p. opolski, opol.; Jablonie; n. ter.; g. Dobrzeń Wielki, p. opolski, opol.; Gablenz, pol. Jabłoniec; wś; g. Jasień, p. żarski, lubus.; Jabłoniec; wś; g. Sulików, zgorzelecki, dśl.; Jabłon$\boldsymbol{k a}$; góra; Góry Sowie, Sudety Środk.; Jablonka; n. ter.; pod Boronowem, g. Herby, p. lubliniecki, śl.; Jabłonka; n. ter.; ok. wsi Brzęczkowice, g. Niemodlin, p. opolski, opol.; Jabłonki; n. ter.; wś Chróścice, g. Dobrzeń Wielki, p. opolski, opol.; Jabłonki; n. ter.; wś Folwark, g. Prószków, p. opolski, opol.; Gablonwald, dziś Jabtoń; las; ok. Kotorza Małego, g. Turawa, p. opolski, opol.; Jablów; wś; g. Stare Bogaczowice, p. wałbrzyski, dśl.

Grusza // hruszka // niem. Birne -'Pirus, drzewo owocowe występujące W wielu gatunkach' [SD II: 1333]. Derywaty: zdr. gruszka, gruszeczka; gruszowiec 'sad gruszkowy', stp. gruszewie 'lasek grusz', por. też gruszkowiec 'gatunek motyli' [SL II: 137]. Niektóre nazwy mogą pochodzić od nazwisk Gruszka (1366), Hruszka (1463).

Przysłowia ludowe zawierające leksem gruszka obrazują ważne prawdy życiowe: Doczkosz sie ty gruszek na wiyrbie, a jo twoji radości [Ond 52]; Wloz na gruszke, siot pietruszke, cap sie mu śmiot [Ond 219]; Najod sie gruszek, a teraz go boli z tego brzuszek [Ond 136]; Nie zaspi gruszek w popiele [Ond 149].

Birnbäumel, dziś Gruszeczka; wś; g. Milicz, p. milicki, dśl.; Gruszka; n. ter.; Goraszowice, g. Otmuchów, p. nyski, opol.; Gruszki; n. ter.; Ciochowice, g. Toszek, p. gliwicki, śl.; Gruszczowie; n. ter.; Stare Siołkowice, g. Popielów, p. opolski, opol.; Gruszowiec; n. ter.; Stradunia, g. Walce, p. krapkowicki, opol.; Gruszów ; n. ter.; Turawa, p. opolski, opol.; Hruszkowiec; n. ter.; Owsiszcze, g. Krzyżanowice, p. raciborski, śl.; fonetyka czes. z obszaru laskiego.

Wiśnia // niem. Kirsche - 'Cerasus Rosaceae, drzewo lub krzew o owocach kulistych, przeznaczonych na desery i przetwory' [SD IX: 1130].

Derywaty: wiśniowy, por. też wiśny 'giętki, ciagły' [SL VI: 340]. Nazwy niemieckie mogą pochodzić od nazwiska niem. $\operatorname{Kirsch}(e)$.

Wiśnicze; wś; g. Wielowieś, p. gliwicki, śl.; Kirschberg, pol. Wiśnica; wzniesienie 165 m, wś Gniewomierz, g. Legnickie Pole, p. legnicki, dśl.; Kirschdorf, pol. Wiśniowa; wś; g. Świdnica, p. świdnicki, dśl.; Kirschberg, pol. Wiśniowa; góra; Góry Izerskie, Sudety Zach.; Kirschberg, pol. Wiśniowa; wzgórze 228 m; g. Marcinowice, p. świdnicki, dśl.; Kirschberg, pol. Wiśniowa; Kirschberg, pol. Wiśniowa; wzgórze; p. świdnicki, dśl.; Kirschallee, pol. Wiśniowa Droga; droga, daw. p. kluczborski, opol.; Kirschberg, pol. Wiśniowa Góra; wzgórze; daw. p. milicki, dśl.; †Wiśniowiec; daw. przys., wś Zamarski, g. Hażlach, p. cieszyński, śl.

Nazwy pochodzące od apelatywu trześnia // niem. Kirsche (od czereśnia // trześnia 'drzewo owocowe, Cerasus avium') wykazują staropolską lub gwarowośląską proweniencję lub wiązać je można z apelatywami trześnia i trześń 
oznaczającymi dziką odmianę czereśni [SD IX: 319], por. Za Trześnie; 1865; pole; wś Nakło, g. Tarnów Opolski, p. opolski, opol.; Kirsch Berg, dziś Trześnik; szczyt; G. Sowie, Sudety Środ.

Niezbyt częsta jest też baza śliwa, śliwka (od śliwa 'drzewo owocowe, Prunus'), por. Śliwkowa Droga; droga leśna; g. Wleń, p. lwówecki, dśl; Śliwkowa Polana; n. ter.; wś Jaworzynka, g. Istebna, p. cieszyński, śl.; por. też nazwiska Śliwa (1482); i liboska (od liboska 'śliwa żniwka o żółtych owocach, często mylona z mirabelką, Prunus domestica'), por. Liboskownia; pole; wś Domecko, g. Komprachcice, p. opolski, opol.

\section{Podsumowanie}

Liczne derywaty apelatywne i zanotowane toponimy potwierdzają fakt, że dla rolnictwa szczególnie ważne były rośliny zbożowe. Stanowiły one podstawę pożywienia ludności wiejskiej, a później wykorzystywane były w przemyśle.

Występowanie w nazewnictwie geograficznym określeń gatunkowych roślin uprawnych łączy się nie tylko z ich uprawą, lecz także z ich znaczeniem symbolicznym i magicznym. Zboże w różnych kulturach i w różnych czasach symbolizowało dar życia, obfitość, płodność, urodzaj i bogactwo. Zarówno kłosy zboża, jak i jego ziarno były znakiem błogosławieństwa i zmartwychwstania [Kop 488]. Ślązacy, podobnie jak pogańscy Słowianie, obchodzili święta związane z porami roku. Były to święta sezonowe, podkreślające wagę dokonujących się zmian w przyrodzie, mające wpłynąć na pomyślność plonów, zapewnić zdrowie czy bezpieczeństwo od suszy lub gradu. Kościół części tych zwyczajów zabronił, a niektóre z nich włączył do praktyk chrześcijańskich. Na przykład obsypywanie ziarnem zbóż, mające przynieść zdrowie i bogactwo, interpretowano jako pamiątkę ukamienowania św. Szczepana. Do kultury chrześcijańskiej zaadaptowano także takie święta ludowe, jak Matki Boskiej Zielnej, podczas którego święcono zboża, zioła i kwiaty, a także jedzono jabłka „od bólu gardła” [Szot-Radziszewska 2005: 144].

Drugą liczną grupę nazw pochodzących od roślin uprawnych stanowią toponimy i mikrotoponimy (w szczególności nazwy górskie) zawierające określenia gatunkowe roślin przemysłowych specjalnych (chmiel, winorośl), które potwierdzają historyczny fakt istnienia plantacji chmielu i winorośli na terenie Śląska.

Produktywność baz zawierających określenia gatunkowe drzew owocowych i innych roślin sadowniczych zwraca uwagę na ich znaczenie w codziennym życiu, medycynie ludowej i przemyśle.

Wykorzystywanie terminologii rolniczej w nazwach miejscowych i terenowych oraz bogata frazeologia i paremiologia z nią związana podkreślają wyjątkowy związek człowieka z przyrodą i pokazują jak człowiek postrzegał otaczający go świat, co odgrywało w jego życiu ważną rolę i stanowiło podstawę jego egzystencji. Obserwacja zmieniających się pór roku, wzrostu, dojrzewania i zbiorów 
poszczególnych typów roślin pozwalała prostemu człowiekowi na wyciagnięcie szerszych wniosków dotyczących natury ludzkiej. Człowiek wyjaśniał sobie pewne zjawiska przyrodnicze, antropomorfizował je, aby w ten sposób oswoić rzeczywistość wokół siebie i stać się częścią wszechświata.

\section{Wykaz skrótów}

\begin{tabular}{|c|c|c|c|}
\hline dorz. & - dorzecze & n. os. & - nazwa osobowa \\
\hline dsl. & - dolnosląskie & n. ter. & - nazwa terenowa \\
\hline folw. & - folwark & opol. & - opolskie \\
\hline g. & - gmina & Pog. & - Pogórze \\
\hline & - Góry & przym. & - przymiotnik \\
\hline kol. & - kolonia & przys. & - przysiółek \\
\hline lbus. & - lubuskie & Śl. & - śląskie \\
\hline & - miasto & wŚ & - wieś \\
\hline & & zach. & - zachodni \\
\hline
\end{tabular}

Byst - Bystroń Jan Stanisław, 1947, Kultura ludowa, Warszawa

Kop - Kopaliński Władysław, 1991, Słownik symboli, Warszawa

Ond - Ondrusz Józef, 1960, Przysłowia i przymówiska ludowe ze Ślqaska Cieszyńskiego, Wrocław

SD - Słownik języka polskiego, 1958-1968, Witold Doroszewski (red.), t. I-X, Warszawa

Sędz - Sędzik Władysław, 1977, Prasłowiańska terminologia rolnicza. Rośliny uprawne. Użytki rolne, Wrocław

SGP - Karłowicz Jan, 1900-1911, Stownik gwar polskich, t. I-VI, Kraków

SL - Linde Samuel Bogumił, 1807-1814, Słownik języka polskiego, t. I-VI, Warszawa [reprint: Warszawa 1951, 1994]

SW - Słownik języka polskiego, 1900-1927, Jan Karłowicz, Adam Kryński, Władysław Niedźwiedzki (red.), t. I-VIII, Warszawa

Pół - Półtorak Zbigniew, 1989, Lecznictwo ludowe rodzimej ludności Opolszczyzny, Opole

Wall - Wallis Stanisław, 1995, Stanisława Wallisa zielnik roślin leczniczych i magicznych, Zofia Brachaczek (opr.), Chorzów

WE - Wielka encyklopedia PWN, 2001-2005, Jan Wojnowski (red.), t. I-XXXI, Warszawa

\section{Bibliografia}

Inglot Stefan, 1954, Gospodarstwo folwarczno-pańszczyźniane od XVI do XVII w. na podstawie dawnej literatury rolniczej, [w:] Krzysztof Kluk (red.), O rolnictwie, zbożach, łakach, chmielnikach, winnicach i roślinach gospodarskich, Wrocław (reprint: Wrocław 2006).

Kluk Krzysztof, 1954, O rolnictwie, zbożach, łakach, chmielnikach, winnicach i roślinach gospodarskich, Wrocław, (reprint: Wrocław 2006).

Kuźniewski Eugeniusz, Augustyn-Puziewicz Janina, 1984, Przewodnik ziołolecznictwa ludowego, Warszawa-Wrocław.

Moszyński Kazimierz, 1967, Kultura ludowa Stowian, t. I, Kultura materialna, Warszawa.

Simonides Dorota, Kowalski Piotr (red.), 1991, Kultura ludowa ślaskiej ludności rodzimej, Wrocław-Warszawa. Sochacka Stanisława, 2000, Wieś ślaska w świetle polskich nazw terenowych, „Śląsk Opolski” 1 (38), 1-6. 
Słownik etymologiczny nazw geograficznych Ślaska, 1970, Stanisław Rospond (red.), t. I, Warszawa-Wrocław; 1985, 1986, Henryk Borek, Stanisław Rospond (red.), t. II-III, WarszawaWrocław; 1988, Henryk Borek (red.), t. IV, Warszawa-Wrocław; 1991-2014, Stanisława Sochacka (red.), t. V-XVI, Opole.

Szot-Radziszewska, 2005, Sekrety ziót. Wiedza ludowa, magia, obrzędy, leczenie, Warszawa.

Tylkowa Danuta, 1989, Medycyna ludowa w kulturze wsi Karpat Polskich. Tradycja $i$ współczesność, Wrocław-Warszawa.

Danuta Lech-Kirstein

\section{Crop names in the Silesian toponymy}

\section{(Summary)}

This paper deals with Silesian macrotoponyms and microtoponyms that originate from the names of crops. These toponyms are part of the linguistic picture of the Silesian world, they show agriculture, pomiculture and horticulture methods and document the most frequently cultivated cereal plants (Jagielnica, Owiesno, Pszów), industrial plants (Chmieliska, Konopowiec, Lniszcze) and orchard plants (Gruszka, Jabłoniec, Za Trześnie). Some databases with names refer to specific times and events (Tabaczana Ścieżka), others are connected with the folk culture, natural medicine, agrarian rites, wedding customs, etc. In the light of these names, one can see the name creator and interpreter of the world, together with their point of view, conceptualization of the world and valuation.

Słowa kluczowe: mikrotoponimia, językowy obraz świata, toponimia Śląska, konceptualizacja świata.

Keywords: microtoponymy, linguistic picture of the world, Silesian toponymy, conceptualization of the world. 